\title{
HUKUM ISLAM DAN DINAMIKA FEMINISME DALAM ORGANISASI NAHDLATUL ULAMA'
}

\author{
Musdah Mulia \\ Pascasarjana UIN Syarif Hidayatullah Jakarta \\ e-mail:m-mulia@indo.net.id
}

\begin{abstract}
The development of the feminist movement has significantly demonstrated in the history of the Nahdlatul Ulama' (NU) organization. In the midst of the discriminatory issues against women and gender mainstreaming bias, $\mathrm{NU}$ consciously and courageously opens up to make space for an expanded discussion of the role of women even in the area of Islamic law (figh), which is considered sacredly. Not only in theoretical-normative, but also $\mathrm{NU}$ showed consistency in the implementation for the ideas of women roles in the public sphere significantly, although a number of issues is still on the agenda of feminist struggle in the Muslimah community, such as violence against women in the household (domestic violence) and gender mainstreaming issues in a variety of positions in the executive, legislative, and judicial branches of government as well as other strategic institutions. The certain thing is that the feminist movement in Indonesia showed a significant effect on the changes in the political, social, legal, and economical areas.
\end{abstract}

[]

Perkembangan gerakan feminisme secara signifikan telah ditunjukkan dalam sejarah perkembangan organisasi Nahdlatul Ulama' (NU). Di tengah isu-isu diskriminatif terhadap perempuan dan anti gender mainstream, NU justru secara sadar dan berani membuka diri untuk memberi ruang diskusi bagi perluasan peran perempuan bahkan pada wilayah hukum Islam (fiqh) yang selama ini disakralkan oleh mereka. Tidak hanya dalam tataran teoritis-normatif, NU menunjukkan konsistensinya dengan mengimplementasikan pemikiran-pemikirannya tentang peran perempuan dalam wilayah publik secara nyata. Meskipun sejumlah persoalan masih menjadi agenda perjuangan feminis dalam komunitas Muslimah, seperti kekerasan terhadap perempuan dalam rumah tangga (domestic violence) dan isu gender mainstreaming dalam berbagai posisi strategis di lembaga-lembaga eksekutif, legislatif, dan yudikatif serta lembaga strategis lainnya, satu hal yang pasti bahwa gerakan feminisme di Indonesia menunjukkan pengaruh yang signifikan terhadap berbagai perubahan di bidang politik, sosial, hukum, dan ekonomi.

Keywords: gender, feminisme, Nahdlatul Ulama', hukum Islam

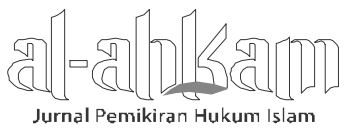




\section{Pendahuluan}

Wacana tentang feminisme selalu kontekstual dan menjadi perdebatan yang tidak pernah berakhir. Disadari atau tidak, wacana ini berkembang, salah satunya karena hasil advokasi para feminis di berbagai belahan dunia. Dengan berbagai argumentasinya, mereka meyakinkan kita bahwa selama berabad-abad perempuan ditindas oleh sebuah sistem yang melibatkan tidak saja kepentingan ekonomi, politik dan ideologi akan tetapi juga agama. Melalui penyadaran akan realitas yang menindas, mereka mencoba melahirkan kritisisme masyarakat demi menciptakan tatanan yang adil, bebas dari segala penindasan terutama terhadap perempuan.

Walaupun belum seluruh masyarakat sependapat dengan argumentasi di atas, dengan alasan yang berbeda-beda, pada umumnya perbedaan pendapat itu muncul karena kerancuan dalam memahami perbedaan antara laki-laki dan perempuan yang bersifat biologis atau kodrati, seperti perbedaan jenis kelamin, fungsi reproduksi dan lain-lain. Perbedaan biologis ini kemudian dikonstruksi secara sosial sehingga melahirkan perbedaan gender. Bagi kaum feminis perbedaan biologis tidak mereka persoalkan, mereka mempersoalkan mengapa perbedaan biologis itu dijadikan justifikasi untuk melakukan pembedaan dan ketidakadilan gender.

Ketidakadilan gender telah berdampak negatif terhadap perempuan, dan termanifestasikan dalam bentuk marginalisasi, ${ }^{1}$ subordinasi, ${ }^{2}$ stereotip, ${ }^{3}$ kekerasan (violence), dan beban kerja yang berat. Melalui penelusuran yang panjang, masingmasing perspektif atau teori feminis mencari akar persoalan, dan menentukan jalan yang harus dilakukan untuk membebaskan perempuan dari ketidakadilan gender tersebut.

Kalangan feminis liberal memiliki pemahaman bahwa semua laki-laki dan perempuan diciptakan seimbang dan serasi, keduanya memilki hak untuk mengembangkan kemampuan rasionalitasnya secara optimal. Tetapi karena adanya seperangkat budaya dan hukum yang membatasi perempuan, sehingga mereka tidak dapat mengembangkan potensi rasionalitasnya secara optimal sebagaimana

\footnotetext{
1Marginalisasi suatu bentuk peminggiran terhadap perempuan yang sering berakibat pada pemiskinan perempuan.

2Subordinasi adalah pandangan yang rendah terhadap perempuan.

${ }^{3}$ Stereotip adalah pelabelan negatif dengan melekatkan sifat-sifat tertentu yang dikaitkan dengan status dan fungsi biologis perempuan.
}

38 || Volume 23, Nomor 1, April 2013

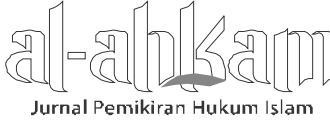


laki-laki. Kunci dari penghapusan diskriminasi dan ketimpangan sosial atas dasar gender terletak terutama pada pendidikan, pembukaan kesempatan kerja seluasluasnya kepada perempuan dan adanya produk hukum yang melindungi perempuan dari segala bentuk diskriminasi dan menjamin mereka dapat berpartisipasi dalam pembangunan.

Dalam bidang politik, perempuan masih banyak mengalami diskriminasi. Mengacu kepada pendapat kalangan feminis liberal, hal ini disebabkan: pertama, perempuan tidak memiliki akses dan kesempatan yang sama untuk berpartisipasi dalam bidang tersebut. Kedua, perempuan belum memiliki kapasitas rasional yang sebanding dengan laki-laki, terutama berkaitan dengan pengetahuan politik.

Pandangan kedua dianut oleh kalangan feminis radikal. Aliran ini berpendapat bahwa sejak awal struktur masyarakat dilandaskan pada hubungan hierarkies berdasarkan jenis kelamin. Laki-laki sebagai kategori sosial yang mendominasi, sedangkan perempuan merupakan objek dari dominasi tersebut. Gender system ${ }^{4}$, ini yang kemudian melahirkan ideologi patriarki, yang menganggap bahwa lakilaki secara kodrati memiliki superioritas atas perempuan, bukan saja dalam arena kehidupan pribadi, tetapi juga masyarakat dan kehidupan bernegara. Bagi penganut paham ini, satu-satunya jalan untuk menghapus segala bentuk ketidakadilan gender adalah dengan membongkar sistem yang sudah mapan sehingga posisi perempuan dan laki-laki menjadi setara dalam semua tingkatan, keluarga, masyarakat dan negara.

Feminis marxis-sosial menganut pandangan, bahwa penindasan terhadap kaum perempuan harus ditelusuri melalui relasi produksi dan nilai patriarki. Isu perempuan dengan demikian, harus diletakan pada kerangka kritik terhadap kapitalisme. Dalam modus produksi, laki-laki dan perempuan memiliki akses yang berbeda.

Hasil kerja perempuan selalu dinilai dalam analisis hubungan women's work status dan women self image. Analisis hubungan ini menjadi akar opresi (ketertindasan) perempuan, karena tidak akan memperoleh pekerjaan yang sama dengan laki-laki. Kalau pun mendapat pekerjaan, jenis pekerjaan yang sama akan dinilai secara berbeda. Konklusi yang dapat diambil adalah bahwa opresi per-

\footnotetext{
${ }^{4}$ Gender sistem merupakan sistem hubungan bermasyarakat yang berlandaskan pada hubungan hierarkis, dimana laki-laki mendominasi, sedangkan perempuan tersubordinasi.
}

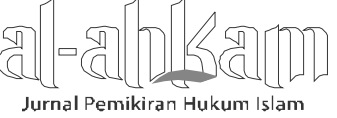


empuan bukan disebabkan oleh dirinya sendiri, tetapi lebih banyak ditentukan oleh superstruktur: ekonomi, sosial dan politik.

\section{Isu Feminisme dalam Tradisi Islam}

Feminisme $^{5}$ adalah gerakan emansipasi ${ }^{6}$ perempuan yang mulai dikenal sekitar abad ke-18. Timbulnya revolusi Perancis (1789) dan revolusi Industri pada abad ke-18 telah mempengaruhi tata hubungan antara laki-laki dan perempuan. Kondisi ini menyebabkan tidak sedikit kaum laki-laki yang terserap di sektor industri, sementara kaum perempuan hanya berkutat dalam sektor domestik (rumah tangga). Ketidakberdayaan kaum perempuan di tengah struktur dan kultur masyarakat industri inilah yang antara lain mendorong lahirnya gerakan feminisme.

Berbeda dengan banyak "isme" lainnya, feminisme bukanlah suatu konsep dan teori yang tunggal. Meskipun demikian, tetap ada pemaknaan yang dapat disepakati bersama mengenai apa itu feminisme. Setiap gerakan feminisme selalu mengandung dalam dirinya suatu "kesadaran feminis" yaitu kesadaran akan adanya perlakuan tidak adil terhadap perempuan, baik di ranah publik maupun di ranah domestik, serta suatu tindakan sadar oleh perempuan maupun laki-laki untuk mengubah kondisi timpang tersebut.

Berdasar perspektif kesadaran feminis tersebut, Nabi Muhammad dapat digolongkan sebagai feminis. Beliau adalah pemimpin revolusioner yang mengangkat derajat perempuan dan menempatkannya pada posisi yang sangat tinggi dengan melawan mainstream kultur pada masanya. Perombakan dan perubahan radikal terhadap posisi perempuan dilakukan melalui tiga isu, yakni isu mahar, waris dan poligami. Sebelum Islam, perempuan adalah objek yang tidak punya hak untuk

\footnotetext{
${ }^{5}$ Kata feminisme berasal dari bahasa Latin, femina yang berarti "perempuan", yaitu penekanan terhadap kualitas perempuan. Istilah ini mulanya digunakan terutama sebagai referensi tentang persamaan seks (sex equality) dalam gerakan pembebasan perempuan. Pada prinsipnya gerakan ini memperjuangkan persamaan hak antar manusia, tanpa membedakan jenis kelamin mereka. Istilah feminisme mulai dikenal di Barat sejak tahun 1890-an. Istilah lain yang sering dipakai untuk menamakan gerakan ini, antara lain Womanism, Women's Liberation, Bourgeois Feminism, Career Feminism, Mainstream Feminism, dan Liberal Feminism. Lihat Valerie Bervson, Feminist Political Theory an Introduction (MacMillan: London, 1992), h. 107.

6Emansipasi berasal dari bahasa Inggris emansipation yang berarti "kemerdekaan". Kemerdekaan di sini diartikan sebagai melepaskan diri dari kekuasaan untuk selanjutnya mempunyai kebebasan dalam bertindak, menentukan sikap, atau tidak bergantung pada orang lain.
} 
bersuara, berkarya dan berharta. Tradisi mahar yang diperkenalkan Islam pada substansinya untuk mengingatkan masyarakat ketika itu bahwa perempuan adalah makhluk berharga. Mahar menempatkan perempuan sebagai subjek, sebagai manusia yang memiliki hak properti. Mahar menjadi milik kaum perempuan yang dinikahi, milik itu tidak boleh dirampas oleh siapapun termasuk orang tua mereka.

Sebelum Islam, perempuan tidak mendapatkan hak waris, bahkan dirinya sendiri menjadi bagian dari harta yang diwariskan. Demikianlah, jika seorang suami meninggal, istri-istrinya dapat diwarisi oleh ahli warisnya. Islam menghapus tradisi yang tidak manusiawi itu dan menetapkan hak kewarisan bagi perempuan, meskipun jumlah yang diberikan belum sebanyak bagian kaum laki-laki, mengingat kaum perempuan mada masa itu belum memiliki akses dalam aktivitas ekonomi. Namun, spirit yang dibangun adalah memberikan hak kepada perempuan untuk memiki harta warisan sebagai pengakuan terhadap eksistensinya sebagai manusia yang utuh setara dan sederajat dengan saudara mereka yang laki-laki.

Poligami sudah menjadi tradisi masyarakat Jahiliyah sebelum Islam dan bahkan sudah dikenal berbagai masyarakat dunia jauh sebelum Islam. Sebelum Islam, laki-laki dapat menikahi perempuan dalam jumlah yang tidak terbatas dan tanpa syarat apa pun. Islam datang dan melakukan koreksi total secara radikal terhadap tradisi yang sudah berurat berakar itu dengan menetapkan jumlah maksimal perempuan yang dapat dijadikan istri, yaitu maksimal hanya empat, itupun disertai dengan syarat yang sangat ketat, yakni dapat berlaku adil terhadap mereka, suatu syarat yang hanya orang setingkat Nabi dapat memenuhinya.

Sayangnya ketiga isu yang diusung Islam itu hanya ideal dan bermakna luhur pada tataran normatif, namun tidak terimplementasi sepenuhnya pada tataran empiris dalam realitas kehidupan penganutnya. Buktinya, di berbagai belahan dunia, mayoritas masyarakat Muslim tetap memperlakukan perempuan sebagai makhluk yang tidak berhak bersuara, berkarya, dan berharta. Mahar malah dianggap sebagai harga pembelian seorang perempuan dan karenanya ia boleh dimiliki sepenuhnya dan diperlakukan semena-mena sebagai komoditas tak berharga. Demikian halnya dengan waris, dijadikan sebagai justifikasi penghargaan setengah terhadap perempuan karena dia dianggap hanya setengah makhluk. Praktik poligami di masyarakat Islam dalam realitas sosiologisnya sungguh-sungguh merupakan kejahatan terhadap kemanusiaan (crime against humanity).

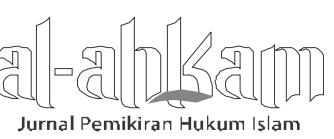




\section{Kesadaran Baru dalam Relasi Gender di Indonesia}

Salah satu isu penting dalam gerakan feminisme di seluruh dunia, termasuk di Indonesia adalah isu gender. Perubahan-perubahan mendasar yang terjadi dalam hampir seluruh aspek kehidupan manusia membawa pengaruh yang tidak kecil terhadap pola relasi gender, terutama kaitannya dengan posisi perempuan dalam keluarga dan masyarakat serta peranannya dalam pembangunan di semua bidang kehidupan. Di tingkat dunia, komitmen untuk mengubah relasi gender ke arah yang lebih adil dan setara terlihat sejak Perserikatan Bangsa-Bangsa (PBB) mengambil langkah-langkah utama dengan menegaskan persamaan hak antara laki-laki dan perempuan dalam piagamnya tahun 1945 dan selanjutnya pada 1946 membentuk Commission on the Status of Women atau CSW (Komisi Kedudukan Perempuan).

Kemudian, CSW sebagai komisi fungsional Economic and Social Council atau ECOSOC berfungsi aktif dalam upaya-upaya peningkatan kedudukan dan peran perempuan selaku mitra sejajar laki-laki, sehingga terwujud kesetaraan dan keadilan gender. Salah satu instrumen fundamental yang dihasilkan berupa Convention on the Elimination of All Forms of Discrimination Against Women disingkat CEDAW (Konvensi Penghapusan Segala Bentuk Diskriminasi terhadap Perempuan) yang disetujui oleh Majelis Umum PBB pada tahun 1979. Indonesia meratifikasi konvensi ini pada tahun 1984 melalui UU No. 7 Tahun 1984. Sayangnya, sampai sekarang Peraturan Pemerintah tentang pelaksanaannya, belum juga dibuat, dan konsekuensinya implementasi isi undang-undang belum terlihat secara konkret dalam kehidupan berbangsa dan bernegara.

Masih di tingkat internasional, perhatian dunia terhadap upaya kesetaraan gender semakin terlihat dengan dicanangkannya tahun 1975 sebagai Tahun Perempuan Internasional oleh PBB, dan tahun 1976 s/d 1985 sebagai Dasa Warsa PBB untuk perempuan. Selama periode ini upaya-upaya pengumpulan dan analisis berbagai data tentang situasi perempuan menjadi prioritas utama bagi PBB dan seluruh badan-badan khususnya. Sungguhpun demikian, analisis data dan indikator yang dikumpulkan dari seluruh dunia menunjukkan bahwa walaupun telah dicapai sejumlah keberhasilan selama seperempat abad terakhir (1975-2000), mayoritas perempuan masih tetap tertinggal jauh di belakang laki-laki dalam seluruh aspek kehidupan, terutama di negara-negara berkembang, seperti Indonesia.

Sebagai respons terhadap situasi perempuan di seluruh dunia yang masih memprihatinkan itu, Konferensi Dunia tentang Hak Asasi Manusia di Wina tahun 
1993 menegaskan perlunya langkah-langkah strategis baru demi memajukan dan melindungi hak-hak perempuan. Deklarasi Wina menekankan dalam pendahuluannya suatu keprihatinan yang mendalam akan perilaku eksploitasi, diskriminasi dan tindak kekerasan yang terus-menerus dihadapi kaum perempuan di berbagai belahan dunia.

Deklarasi dan Program Aksi konferensi ini menegaskan tiga point penting. Pertama, penegasan Hak Asasi Perempuan sebagai bagian yang tak terpisahkan dari Hak Asasi Manusia secara integral (Women `s Rights are Human Rights). Kedua, penegasan partisipasi penuh dan setara bagi perempuan dalam kehidupan politik, sipil, ekonomi, sosial dan budaya pada semua tingkat: nasional, regional, dan internasional serta penghapusan segala bentuk diskriminasi berdasarkan jenis kelamin merupakan tujuan utama masyarakat sedunia. Ketiga, penegasan bahwa kekerasan berbasis gender dan segala bentuknya tidak sesuai dengan martabat dan harga diri manusia serta harus dihapuskan.

Tindak lanjut konkret dari program aksi Konferensi Wina tersebut terlihat dalam Konferensi Internasional Kependudukan dan Pembangunan di Kairo tahun 1994. Melalui konferensi ini masyarakat internasional untuk pertama kalinya mengakui bahwa pemberdayaan perempuan merupakan bagian integral dari pembangunan. Program Aksi Kairo melahirkan sejumlah kesepakatan internasional untuk memajukan kesetaraan dan keadilan gender (gender equality and equity) dalam seluruh bidang pembangunan. Selanjutnya, Konferensi Dunia IV Tentang Perempuan di Beijing (1997) berhasil mengidentifikasi 12 bidang kritis yang dihadapi kaum perempuan di seluruh dunia, Bidang-bidang kritis dimaksud, antara lain: bidang pendidikan, kesehatan, tindak kekerasan terhadap perempuan, ekonomi, pengambilan keputusan, hak asasi perempuan, pemberitaan media, lingkungan hidup, dan hak anak-anak perempuan.

Upaya-upaya untuk membangun kondisi kesetaraan dan keadilan gender di tingkat internasional memberikan dampak positif bagi perjuangan perempuan di seluruh dunia, tak ketinggalan perempuan Indonesia. Secara bertahap Indonesia telah memiliki UU No. 7 Tahun 1984 tentang Pengesahan Konvensi Penghapusan Segala Bentuk Diskriminasi terhadap Perempuan, dan UU No. 39 Tahun 1999 tentang HAM yang isinya sangat menekankan upaya perlindungan dan penguatan terhadap perempuan menuju kepada terwujudnya kondisi kesetaraan dan keadilan gender dalam seluruh aspek kehidupan warga: sosial, ekonomi, dan

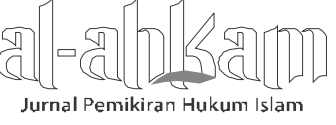


politik, baik dalam kehidupan keluarga, maupun dalam kehidupan berbangsa dan bernegara.

Bahkan, Indonesia telah memiliki Inpres No. 9 Tahun 2000 tentang Gender Mainstreaming (Pengarusutamaan Gender) yang menekankan perlunya pengintegrasian gender dalam seluruh tahap pembangunan nasional: mulai perencanaan sampai tahap evaluasi. Selain itu, UU No. 22 Tahun 1999 tentang Pemerintahan Daerah yang amat tegas menekankan pada prinsip demokrasi dengan ciri partisipasi seluruh masyarakat, tanpa membedakan laki-laki dan perempuan. Selain itu, pemerintah pun telah merativikasi sejumlah Konvensi Internasional, seperti Konvensi Hak Anak, Konvensi ILO mengenai buruh yang isinya memuat secara eksplisit tentang upaya perlindungan dan penegakan terhadap hak-hak perempuan.

Khusus bagi LSM dan kelompok feminis berbasiskan Islam, isu-isu ketimpangan gender mengambil bentuk: Isu kepemimpinan perempuan, mayoritas umat Islam menolak perempuan menjadi pemimpin, baik di ranah domestik terlebih lagi di ranah publik; isu pewarisan, perwalian dan kesaksian bagi perempuan; isu aurat dan jilbab; isu kekerasan di rumah tangga; dan isu-isu di seputar hak dan kesehatan reproduksi perempuan, seperti persoalan khitan perempuan, relasi seksual, perkawinan muda usia, perkawinan mut'ah, kehamilan yang tidak diinginkan, kontrasepsi, aborsi, HIV/AIDS dan lainnya.

Secara normatif, sejumlah instrumen tersebut sudah dapat menjadi landasan aksi perjuangan kelompok feminis di Indonesia untuk mengeliminasi berbagai bentuk diskriminasi seperti terungkap dalam perbincangan isu-isu di atas. Namun, pada kenyataannya seluruh perangkat undang-undang dan berbagai peraturan konvensi itu belum diimplementasikan dalam tataran aksi berupa program kerja konkret pemerintah di lapangan. Akibatnya, sampai sekarang masih dijumpai begitu banyak persoalan ketimpangan gender di masyarakat, seperti isu kesehatan reproduksi, isu pendidikan, isu ekonomi, isu hukum dan perundang-undangan, isu HAM, dan isu politik.

Demikianlah sekelumit gambaran ketimpangan gender di Indonesia, dan anehnya tidak semua kalangan mampu melihat kondisi tersebut sebagai masalah sosial yang krusial. Di sinilah pentingnya analisis gender. Suatu alat analisis yang dapat membantu seseorang mengenali dan mengidentifikasi masalah-masalah sosial di sekitarnya yang disebabkan karena relasi gender yang timpang.

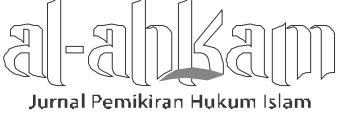




\section{Bagaimana Memahami Hukum Islam?}

Islam sebagai agama, pada hakikatnya terlihat pada aspek nilai-nilai kemanusiaan yang terkandung di dalamnya. Salah satu bentuk elaborasi dari nilainilai kemanusiaan itu adalah pengakuan yang tulus terhadap kesetaraan dan kesatuan manusia. Semua manusia adalah setara dan berasal dari sumber yang satu, yaitu Tuhan. Di hadapan Tuhan, yang membedakan di antara manusia hanyalah prestasi dan kualitas takwanya, dan bicara soal takwa, hanya Tuhan semata memiliki hak prerogatif untuk melakukan penilaian, bukan manusia.

Islam diyakini pemeluknya sebagai agama yang menjanjikan harapan hidup yang lebih baik: menjanjikan kebahagiaan dan kesejahteraan bagi manusia, baik di dunia ini maupun di akhirat kelak. Karena itu, manusia memiliki tempat yang sangat sentral dalam ajaran Islam, sebagai khalïfah fi 'l-arḍ. Islam memandang manusia secara optimis dan positif, yakni sebagai makhluk paling mulia dan bermartabat. ${ }^{7}$ Konsep ini sangat penting, terutama dalam kaitan dengan pemahaman terhadap teks-teks suci keagamaan. Manusia dengan seluruh pengalamannya merupakan dasar yang amat penting dalam memahami teks-teks keagamaan. Kemaslahatan dan kebahagiaan manusia harus menjadi pertimbangan utama dalam menafsirkan teksteks tersebut. Berbeda dengan makhluk lainnya, manusia memiliki posisi yang sangat spesifik, di antaranya berpotensi menjadi khalifah Tuhan ${ }^{8}$ yang tugas utamanya adalah melakukan perbaikan moral. Tugas manusia adalah menerjemahkan karya kreatif Tuhan di alam semesta. Karena itu, keunikan manusia adalah bahwa ia mewakili Tuhan di atas bumi ini. Suatu posisi yang teramat tinggi, bahkan belum pernah diberikan kepada makhluk lainnya, termasuk malaikat sekali pun.

Umat Islam hampir sepakat mengenai pentingnya ijtihad, yaitu penggunaan akal pikiran dalam memahami hukum-hukum Tuhan. Ijtihad merupakan suatu kebutuhan dasar, bukan hanya setelah Rasul tiada, bahkan ketika masih hidup. Sebab, menurut Wahhāb Khallāf, pakar hukum Islam ternama, meskipun al-Qur'an mengandung ketentuan hukum yang cukup rinci, namun jumlahnya amat sedikit dibandingkan dengan begitu banyaknya persoalan sosial manusia yang memerlukan ketentuan hukum. ${ }^{9}$

${ }^{7}$ QS. al-Baqarah: 30 dan QS. al-Isrä': 70.

${ }^{8}$ QS. al-Baqarah: 30.

${ }^{9}$ Penelitian 'Abdul Wahhāb Khallăf, pakar ușūl al-fiqh, mengenai ayat-ayat hukum menjelaskan bahwa jumlah ayat al-Qur'an yang berisi ketentuan hukum secara tegas hanya sekitar 5,8\% atau sebanyak 368 ayat saja, sedangkan jumlah yang terbesar justru berisi nilai-nilai universal, seperti 
Akan tetapi, masalah paling mendasar dalam pemahaman keagamaan mayoritas umat Islam adalah mereka telanjur meyakini kebenaran teks sebagai sesuatu yang mutlak dan abadi, sehingga mengabaikan kenyataan dan pengalaman manusia yang konkret. Mereka terpaku pada makna-makna literalis tanpa menghiraukan konteks ajaran dan bahkan mengabaikan tujuan dasar dari ajaran Islam itu sendiri, yakni kemaslahatan umat manusia. Itulah yang terjadi dalam pemahaman umat Islam menyangkut relasi gender.

Mayoritas umat Islam meyakini bahwa semakin ketat memegangi makna literalis teks dipandang sebagai semakin dekat dengan Islam, sebaliknya semakin jauh seseorang meninggalkan makna tekstual tersebut dipandang semakin jauh dari Islam. Dengan demikian, kata Abū Zayd, peradaban Islam yang terbangun kini tidak lain adalah peradaban teks. ${ }^{10}$ Padahal, agama diturunkan untuk memenuhi kebutuhan hakiki manusia berupa kemaslahatan, kebahagiaan dan ketenteraman. Agama Islam diturunkan bukan untuk kemaslahatan dan kepentingan Tuhan sebab Dia Mahakuasa, Dia Maha Sempurna dan tidak membutuhkan apa pun dari makhluk-Nya. Akan tetapi, dalam realitas sosiologis di masyarakat, Islam lebih banyak diamalkan untuk "menyenangkan Tuhan" sehingga hampir-hampir tidak menyisakan manfaat bagi kemanusiaan. Karena itu diperlukan ijtihad yang menggunakan analisis sosial untuk merekonstruksi ajaran Islam sehingga betul-betul kompatible (sesuai) dengan kemaslahatan dan kebahagiaan manusia.

Memahami posisi perempuan dalam Islam harus tetap mengacu kepada sumber-sumber Islam yang utama, yakni al-Qur'an dan Sunnah. Hanya saja pemahaman terhadap kedua sumber tadi tidak semata didasarkan kepada pemaknaan tekstual, melainkan memperhatikan juga segi kontekstualnya, baik konteks makro berupa tradisi masyarakat Arab dan kondisi sosio-politik dan sosio-historis ketika itu maupun konteks mikro dalam wujud asbāb al-nuzūl ayat dan asbāb alwurūd hadis. Pemaknaan non-literal terhadap teks-teks suci agama dalam alQur'an dan Sunnah mengacu kepada tujuan-tujuan hakiki syariat atau yang lazim disebut dengan maqāșid al-sharīah. ${ }^{11}$

keadilan, cinta kasih, kedamaian, dan kebebasan yang kesemuanya merupakan pesan-pesan moral keagamaan yang dapat dijadikan pedoman dalam kehidupan bermasyarakat. Lihat 'Abdul Wahhāb Khalläf, IIm Ușul al-Fiqh, cet. VII (Kairo: t.p., 1956), h. 34-35.

${ }^{10}$ Penjelasan yang luas mengenai hal ini lihat Nașr Hāmid Abū Zayd, Mafhūm al-Naṣ: Dirāsāt fi 'Ulūm al-Qur'ān (Kairo: al-Ḥayyah al-Mișriyyah al-'Āmmah li 'l-Kitāb, 1993), h. 11.

${ }^{11}$ Istilah ini pertama kali diperkenalkan oleh Abū Ishāq al-Shātịī dalam bukunya yang terkenal: al-Muwāfaqāt fi Ușūl al-Sharīah. Akan tetapi, konsep ini sudah disinggung sebelumnya oleh alJuwaynī Imām al-Ḥaramayn dan Abū Ḥāmid Muḥammad al-Ghazālī.

46 || Volume 23, Nomor 1, April 2013

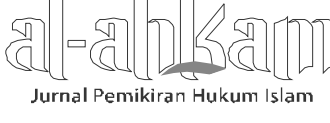


Tujuan hakiki syariat Islam adalah mewujudkan kemaslahatan manusia melalui perlindungan terhadap lima hak dasar manusia (al-kulliyah al-khamsah), yaitu: hak hidup (hifz al-nafs), hak kebebasan beragama (hifż al-dinn), hak beropini dan berekspresi (hifz al-'aql), hak reproduksi (hifz al-nasl), dan hak properti (hifz al-māl) menuju kesejahteraan dan kebahagiaan lahir batin, baik di dunia dan di akhirat. Terhadap semua pemahaman keislaman yang tidak kondusif terhadap pemenuhan hak-hak dasar tersebut perlu dikaji ulang, bahkan kalau perlu dilakukan dekonstruksi ajaran. Hal ini karena pemahaman agama sangat ditentukan oleh perspektif penafsirnya yang seringkali tidak bisa melepaskan diri dari pengaruh sosio-kultural dan sosio-politik yang berkembang di masanya. Akan tetapi, mengubah interpretasi agama bukan hal yang mudah karena agama selalu diidentikkan dengan kebenaran mutlak, sakral, dan bersifat ilahiyah. Bahkan, menjadi lebih sulit lagi karena seringkali yang diklaim sebagai agama ternyata hanyalah penafsiran dari pemilik otoritas agama, bukan agama itu sendiri. Itulah problemnya!

Konsep al-ḥuqūq al-khamsah ini selanjutnya membawa kepada pentingnya melihat manusia sebagai sasaran sekaligus subjek hukum dalam syariat Islam. Oleh karena itu, tidak berlebihan jika Ibn al-Qayyim al-Jawziyyah, ahli fikih dari Mazhab Hanbali, merumuskan sebagai berikut: syariat Islam sesungguhnya dibangun untuk kepentingan manusia dan tujuan-tujuan kemanusiaan yang universal, seperti kemaslahatan, keadilan, kerahmatan, kebijaksanaan. Prinsip-prinsip inilah yang harus menjadi acuan dalam pembuatan hukum dan juga harus menjadi inspirasi bagi setiap pembuat hukum. Penyimpangan terhadap prinsip-prinsip ini berarti menyalahi cita-cita hukum Islam itu sendiri. ${ }^{12}$ Pernyataan yang tidak kurang tegasnya dilontarkan oleh Ibn Rushd: bahwa kemaslahatan itu merupakan akar dari berbagai syariat yang ditetapkan Tuhan. ${ }^{13}$ Bahkan, 'Izz al-Dīn ibn 'Abd alSalām sampai kepada kesimpulan bahwa seluruh ketentuan syariat Islam diarahkan sepenuhnya untuk memenuhi kemaslahatan manusia. ${ }^{14}$

Berangkat dari teori maqāṣid al-sharīah ini, Ibn Muqaffa` mengklasifikasikan ayat-ayat al-Qur'an ke dalam dua kategori: āyāt uṣūliyyah yang bersifat universal

\footnotetext{
${ }^{12}$ Ibn al-Qayyim al-Jawziyyah, I'lām al-Muwaqqiîn 'an Rabb al-'Ālamin, Juz III (Beirut: Dār al-Jīl, t.th), h. 3. Pandangan serupa dinyatakan oleh ulama yang sangat otorotatif di bidang fikih, seperti alGhazālī (w. 505H); Fakhr al-Dīn al-Rāzī (w. 606 H); 'Izz al-Dīn ibn 'Abd al-Salām (w. 660 H); Najm alDīn al-Ṭūi (w. 716 H); Ibn Taymiyyah (w. 728 H.); Abū Isḥāq al-Shāțibī (w. 790 H.); dan Muhammad ibn Ṭāhir al-Ashūr (w. 1393 H.).

${ }^{13}$ Ibn Rushd, Faṣl al-Maqāl fi Taqrīr Mā bayna I-Sharīat wa T-Hikmah min al-Ittisāl aw Wujūh alNaẓar al-'Aqli wa Ḥudūd al-Ta wīl (Beirut: Dirāsah al-Wiḥdah al-'Arabiyyah, 1999), h. 125.

14'Izz al-Dīn ibn ‘Abd al-Salām, Qawāid al-Ahkām fi Mașālị̣ al-Anām (t.t.p.: Dār al-J̄l, t.th.), h.. 72.

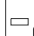

Jurnal Pemikiran Hukum Islam 
karena menerangkan nilai-nilai utama dalam Islam, dan āyāt furū ìyyah yang bersifat partikular karena menjelaskan hal-hal yang spesifik. Contoh kategori pertama adalah ayat-ayat yang berbicara soal keadilan, sedangkan kategori kedua adalah ayat-ayat yang mengulas soal uqūbāt (bentuk-bentuk hukuman), dan ḥudūd (bentuk-bentuk sanksi), serta ayat-ayat yang berisi ketentuan perkawinan, waris, dan transaksi sosial. Sayangnya umat Islam lebih banyak merujuk pada ayat-ayat partikular, dan mengabaikan ayat-ayat universal. Umat Islam terbelenggu pada pandangan fikih ketimbang menggali pesan-pesan moral agama dibalik teks-teks suci.

Fikih yang kita kenal sekarang merupakan rekayasa cerdas pemikiran ulama abad pertengahan yang isinya mencakup empat komponen dasar, yaitu masalah 'ubūdiyyah (membahas hubungan transendental manusia dengan Tuhan), mu'āmalah (membahas hubungan manusia dengan sesamanya, makhluk lain dan alam semesta), munākahāt (membahas hubungan manusia dengan manusia dalam kehidupan keluarga), dan jināyah (membahas berbagai masalah pidana). Seluruh komponen tersebut merupakan teknis operasional dari lima prinsip dasar (alhuqūq al-khamsah) yang dirumuskan al-Ghazālī.

Fikih adalah formulasi pemahaman Islam yang digali dari al-Qur'an dan sunnah, karena itu tentu saja sifatnya tidak absolut dan tidak pasti (ẓannī). Sebagai hasil rekayasa cerdas pemikiran manusia, tidak ada jaminan bahwa pandangan itu tidak mengandung kesalahan atau kekeliruan di dalam dirinya. Suatu hasil ijtihad biasanya selalu dipengaruhi oleh faktor-faktor sosio-kultural dan sosio-historis masyarakat di sekitarnya atau pada masa kehidupan ulama tersebut. Oleh karena itu, suatu hasil ijtihad tidak mungkin berlaku abadi untuk semua manusia sepanjang masa. Boleh jadi hasil ijtihad tersebut cocok untuk kurun waktu tertentu, namun belum tentu cocok untuk kurun waktu yang lain. Boleh jadi suatu ijtihad cocok untuk suatu masyarakat tertentu, namun belum pasti untuk masyarakat lainnya yang memiliki budaya dan kebutuhan yang berbeda. Artinya, kita dapat menerima suatu hasil ijtihad, tetapi penerimaan itu tidak harus menghalangi kita bersikap kritis, atau mencegah kita menerima hasil ijtihad lain yang berbeda tetapi justru sangat sesuai dengan kemaslahatan manusia.

\section{Dinamika Hukum Islam dan Gerakan Feminisme dalam Organisasi Nahdlatul 'Ulama'}

Gambaran mengenai gerakan feminisme di Indonesia, terutama di kalangan Islam belumlah lengkap tanpa menyibak bagaimana isu-isu feminisme di- 
perbincangkan di lingkungan organisasi NU. NU selama ini dikenal sebagai suatu gerakan Islam tradisional, khususnya dalam pandangan dan pemahamannya mengenai pemikiran Islam.

Para pengamat umumnya melihat sosok Gus Dur sebagai tokoh yang merintis pemikiran liberal di NU. Ia diakui banyak memberikan perlindungan pada generasi muda NU yang haus akan pemikiran baru dan suka berpikir kritis, baik dalam masalah agama maupun bidang politik. Karena itu, tidak mengherankan kalau di tubuh NU, terutama di kalangan mudanya, terlihat suatu suasana diskusi yang lebih bebas dibandingkan dengan suasana yang sama pada ormas Islam lainnya, bahkan pada ormas yang non-Islam.

Sebetulnya, Gus Dur sendiri memprediksikan bahwa dalam dekade terakhir ini telah terjadi proses identifikasi diri yang luar biasa di tubuh NU. Di dalam tubuh NU muncul gagasan reformasi dan transformasi yang apresiatif terhadap upaya-upaya membangun masyarakat Indonesia modern; muncul gagasan yang apresiatif terhadap demokrasi, hak asasi, pluralisme, dan unsur-unsur masyarakat sipil modern lainnya. Hal ini mengindikasikan bahwa komunitas NU ternyata merupakan suatu komunitas dengan vitalitas yang cukup untuk menyerap dan berhubungan dengan perubahan sosial dalam bentuknya yang rasional, tanpa harus kehilangan pesan-pesan moralnya.

Isu-isu feminisme, khususnya yang berkaitan dengan isu kesetaraan gender, di kalangan organisasi NU telah lama dibicarakan walaupun ketika itu belum menggunakan terminologi kesetaraan gender, melainkan istilah emansipasi perempuan.Hal itu, misalnya dapat dirunut dari upaya K.H. Bisri Syamsuri (mertua Gus Dur) mendirikan Pesantren Putri di Denanyar, sebuah pesantren yang dikhususkan bagi kaum perempuan pada akhir tahun 1920-an. Meski pada mulanya mendapat tantangan keras dari tokoh-tokoh NU, termasuk dari pendiri NU sendiri, KH Hasyim Asy'ari (1871-1947), berkat kegigihan dan kesungguhan Kyai Bisri, pesantren putri ini dapat berdiri dan selanjutnya berkembang dengan pesat.

Gagasan berikutnya, muncul dari K.H. Wahid Hasyim (1914-1953). Selaku Menteri Agama RI, Beliau mengeluarkan satu kebijakan publik yang membolehkan kaum perempuan memasuki Fakultas Syari'ah, dan sebagai konsekuensi logis dari kebolehan itu adalah terbukanya akses dan kesempatan bagi perempuan menjadi hakim agama, suatu posisi yang dalam kitab fikih klasik hanya diperuntukkan bagi laki-laki, dan haram bagi perempuan. 
Dewasa ini, perempuan yang berprofesi sebagai hakim agama dijumpai di semua kantor Pengadilan Agama di seluruh pelosok nusantara, meskipun diakui jumlahnya masih lebih sedikit dibanding hakim agama laki-laki. Dalam konteks ini, Muslimah Indonesia lebih maju dan lebih berdaya dibandingkan dengan Muslimah di Arab Saudi atau di Malaysia yang sampai sekarang masih mengharamkan perempuan menjadi hakim agama.

Berikutnya, Konferensi Besar Syuriah NU tahun 1957 menyepakati suatu keputusan yang melegitimasi bolehnya perempuan memasuki lembaga legislatif, baik di DPR Pusat maupun DPR Daerah. Tentu saja untuk ukuran masa itu, keputusan ini dirasakan sangat progresif, apalagi di lingkungan dunia Islam yang ketika itu sama sekali tidak memberikan ruang kepada perempuan untuk berkiprah di bidang politik. Menyusul kemudian, Keputusan Muktamar NU tahun 1962 di Salatiga yang memperkenankan perempuan duduk di lembaga eksekutif sebagai Kepala Desa.

Pengakuan NU akan kebolehan perempuan berkiprah di ruang publik, baik di lembaga yudikatif, maupun legislatif dan eksekutif bukan hanya ada di tingkat wacana, melainkan juga berlaku di tingkat aksi. Buktinya, pada masa-masa selanjutnya dijumpai wakil perempuan $\mathrm{NU}$ di berbagai lembaga yang disebutkan tadi. Selain itu, keterlibatan kaum perempuan di tubuh organisasi NU tingkat pusat juga semakin konkret. Hal itu ditunjukkan dengan masuknya sejumlah tokoh Muslimat NU, seperti Nyai Fatimah, Nyai Mahmudah Mawardi, dan Nyai Choiriyah Hasyim dalam kepengurusan Syuriah PBNU tahun 60-an.

Namun, sangat disayangkan bahwa pada generasi sesudah ketiga tokoh perempuan yang disebutkan di atas, tidak lagi ditemukan dalam catatan sejarah mengenai keterlibatan perempuan dalam kepengurusan PBNU. Tidak jelas apa alasannya sehingga partisipasi perempuan dalam kepengurusan PBNU bukannya semakin meningkat, malah sebaliknya semakin menurun. Pengurus perempuan hanya ditempatkan pada posisi $a$ wān (anggota biasa) sebagaimana dalam kepengurusan PBNU sekarang.

Pembicaraan serius mengenai pemberdayaan perempuan di tubuh $\mathrm{NU}$ kembali mengemuka pada Musyawarah Nasional Alim Ulama NU di Lombok tahun 1997. Munas tersebut melahirkan suatu keputusan atau maklumat tentang "Kedudukan Perempuan dalam Islam" (Makānat al-Mar'ah fi 'l-Islām). Pokokpokok pikiran yang terkandung dalam maklumat tersebut dapat disimpulkan dalam 5 poin: 1) Islam mengakui eksistensi perempuan sebagai manusia yang utuh 
dan karenanya patut dihormati; 2) Islam mengakui hak perempuan sama dengan hak laki-laki dalam hal pengabdian kepada agama, nusa, dan bangsa; 3) Islam mengakui adanya perbedaan fungsi antara laki-laki dan perempuan yang disebabkan karena perbedaan kodrati; 4) Islam mengakui peran publik perempuan di samping peran domestiknya; dan 5) Ajaran Islam yang menempatkan perempuan pada posisi yang setara dengan laki-laki itu dalam realitasnya telah mengalami distorsi akibat pengaruh kondisi sosial dan budaya.

Meskipun masih terasa ada bias nilai-nilai patriarkhi dalam maklumat tersebut, misalnya pernyataan bahwa peran domestik perempuan yang hal itu merupakan kesejatian kodrat wanita, seperti sebagai pendidik yang pertama dan utama bagi anak-anak mereka dan seterusnya. Artinya, dalam maklumat itu kodrat perempuan masih dipahami bias gender, namun paling tidak maklumat itu telah menegaskan pengakuan akan kebolehan kaum perempuan berkiprah di dunia publik yang selama ini dianggap sebagai monopoli kaum laki-laki. Terpenting dan sangat mendasar adalah bahwa di akhir maklumat tersebut terbaca komitmen NU yang kuat untuk meningkatkan partisipasi perempuan dalam seluruh aspek kehidupan. NU menyatakan komitmennya untuk ikut memprakarsai transformasi kultur kesetaraan yang pada gilirannya mampu menjadi dinamisator pembangunan Nasional dalam era globalisasi dengan memberdayakan perempuan Indonesia pada proporsi yang sebenarnya.

Bagi kalangan perempuan, khususnya bagi organisasi perempuan di lingkungan $\mathrm{NU}$, maklumat ini merupakan dokumen historis yang amat strategis yang dapat dijadikan dasar legitimasi dan advokasi bagi upaya-upaya pemberdayaan perempuan yang sebelumnya masih sangat kontroversial di lingkungan NU. Perlu diketahui bahwa hasil keputusan Munas Alim Ulama ketika itu mengenai Masā'il Dīniyyah Mawḍūìyah mencakup empat tema pokok: 1) Nasb al-Imām dan Demokrasi; 2) Hak Asasi Manusia dalam Islam; 3) Kedudukan Wanita dalam Islam; dan 4) Reksadana.

Menarik dicatat bahwa Munas NU tersebut secara intens membahas masalah demokrasi dan hak-hak asasi manusia (HAM), dua isu yang sedang menjadi tema pokok dalam setiap diskursus ilmiah, baik dalam forum Nasional, maupun internasional. Kedua isu itu amat terkait dengan pembicaraan soal kesetaraan gender yang menjadi isu global saat ini. Terlepas dari kontroversi penilaian orang luar terhadap maklumat tadi, yang penting digarisbawahi bahwa di akhir maklumat tersebut terbaca komitmen NU yang begitu kuat untuk meningkatkan

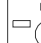

Jurnal Pemikiran Hukum Islam 
partisipasi perempuan. Di sana tertulis bahwa NU bertekad memprakarsai transformasi kultur kesetaraan yang pada gilirannya mampu menjadikan perempuan sebagai dinamisator pembangunan Nasional dalam era globalisasi dengan memberdayakan perempuan Indonesia pada proporsi yang sebenarnya.

Tuntutan mengenai perlunya ada wakil perempuan dalam PBNU selanjutnya dinyatakan secara resmi oleh organisasi Muslimat NU. Seminar yang bertemakan "Membuka Cakrawala Baru Perempuan di NU" diselenggarakan PP. Muslimat NU pada 10 November 1999 di Jakarta, beberapa hari menjelang pelaksanaan Muktamar NU di Lirboyo, Kediri. Seminar tersebut antara lain merekomendasikan perlunya langkah-langkah konkret NU untuk merealisasikan isi maklumat NU 1997 tersebut dalam bentuk merekrut kalangan perempuan NU untuk didudukkan pada struktur kepengurusan PBNU yang akan datang, baik pada tingkat Syuriyah, maupun pada tingkat Tanfiziyah.

Eksistensi perempuan dalam struktur kepengurusan PBNU dirasakan sangat strategis mengingat bahwa semua keputusan dan program-program PBNU menjadi acuan dari seluruh organisasi badan otonom dan semua lembaga yang ada di tubuh NU. Karena itu, keikutsertaan perempuan dalam perumusan keputusan dan kebijakan di tingkat PBNU dirasakan sangat strategis agar keputusankeputusan yang dihasilkan tidak bias gender dan selalu memperhatikan kepentingan kaum perempuan yang secara kuantitas jumlahnya sama, atau bahkan lebih bannyak dari kaum laki-laki.

Sebagai contoh, berikut ini akan dikemukakan rumusan Program Umum NU Masa Khidmah 1989-1994 hasil Muktamar NU Ke-28 yang berbicara soal perempuan:

"Peranan wanita dalam pembangunan masyarakat (terutama masyarakat pedesaan) cukup besar. Untuk meningkatkan keberhasilan yang selama ini sudah dicapai. masih diperlukan penyempurnaan di kalangan Muslimat, Fatayat, dan IPPNU, baik dari segi organisasi maupun kualitas kegiatannya, melalui upayaupaya: konsolidasi organisasi dan meningkatkan usaha sosial yang selama ini telah ditempuh, seperti rukun kematian, penyantunan yatim piatu, pemberian bea-siswa (anak asuh), pelayanan kepada orang jompo, mempererat silaturahim, serta meningkatkan usaha-usaha di bidang kesehatan, terutama yang langsung menyangkut kebutuhan ibu dan anak, seperti BKIA, klinik KB, pembinaan balita dan sebagainya".

Lima butir kegiatan yang direkomendasikan NU untuk dilakukan oleh segenap organisasi perempuan NU di atas tampaknya masih sangat terfokus pada kegiatankegiatan yang menjangkau kepentingan praktis untuk kesejahteraan perempuan 
(women welfare concern), belum sampai menyentuh pada kepentingan strategis perempuan.

Mari kita perhatikan hasil Muktamar NU berikutnya, (Muktamar NU ke-29) tentang Program Pokok Pengembangan NU 1994-1999 sektor wanita:

“Melalui Badan Otonom Wanita (Muslimat dan Fatayat) NU ikut serta mengembangkan dan mendorong peningkatan peran wanita dalam kehidupan berbangsa, bernegara, bermasyarakat, dan beragama dengan pembekalan pengetahuan dan peningkatan keterampilan. Di samping itu juga ikut serta dalam program-program sosial kemasyarakatan seperti bidang kesehatan, pendidikan, dan budaya secara umum."

Rumusan hasil keputusan Muktamar NU Ke-29 ini pun secara substansial tidak berbeda dengan hasil keputusan Muktamar sebelumnya, yaitu masih menekankan pada kepentingan kesejahteraan perempuan (women welfare concern). Karena itu, tidak mengherankan jika hasil keputusan kongres dari ketiga organisasi perempuan di bawah NU juga masih menfokuskan programnya pada kegiatankegiatan yang bernuansa kepentingan kesejahteraan perempuan (women welfare concern), dan belum menyentuh persoalan yang hakiki, yakni kepentingan strategis perempuan. ${ }^{15}$

Tuntutan ke depan diharapkan agar semua organisasi perempuan NU memfokuskan programnya pada kepentingan strategis gender dalam rangka menangani dan mengatasi berbagai problem sosial yang muncul sebagai dampak dari kesenjangan gender dan diskriminasi gender. Isu gender harus dimunculkan karena selama ini telah terjadi kesenjangan gender dalam bentuk diskriminasi gender. Dalam setiap tahapannya isu gender akan mempengaruhi upaya pembangunan dalam memenuhi kepentingan perempuan. Sebagai contoh, masalah pemenuhan kebutuhan gizi bagi perempuan hamil adalah merupakan bagian dari kepentingan khusus perempuan, tetapi masalah ini erat kaitannya dengan kenyataan bahwa perempuan tidak memiliki akses yang cukup terhadap pendapatan keluarga.

Dari uraian di atas dapat disimpulkan bahwa meskipun upaya-upaya untuk memajukan posisi perempuan sudah berlangsung lama dalam tubuh $\mathrm{NU}$, namun tetap saja isu-isu feminisme belum dianggap sebagai isu penting dan prioritas di lingkungan NU. Karena itu, kalangan feminis di NU masih menghadapi sejumlah

\footnotetext{
15Lihat Sejarah Fatayat NU, PP Fatayat NU (Jakarta: t.p, 2005).
}

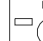

Jurnal Pemikiran Hukum Islam 
kendala, baik yang bersifat internal maupun eksternal, dalam upaya aktualisasi ajaran Islam berperspektif gender di lingkungan NU menuju tatanan hubungan baru antara perempuan dan laki-laki NU yang lebih demokratis, egaliter, dan berkeadilan. Kendala itu dapat diatasi jika NU mempunyai komitmen yang kuat untuk melakukan proses penyadaran, dan tentu saja ini dilakukan bukan hanya pada tataran wacana, melainkan lebih ditegaskan pada tataran aksi nyata.

Salah satu faktor menonjol yang menghambat kemajuan perempuan NU adalah karena mayoritas mereka tidak mengetahui hak-haknya yang dijamin oleh agama. Salah satu penyebabnya adalah karena pada umumnya kitab-kitab fikih yang dipakai di kalangan pesantren NU, hampir semuanya buah karya laki-laki dan kemudian diajarkan oleh laki-laki sehingga mudah dimengerti jika prasangka dan kepentingan kaum laki-laki sangat mewarnai pembahasannya. Tidak heran kalau ajaran yang tersosialisasi di masyarakat sarat dengan muatan nilai-nilai yang bias laki-laki (male bias). Sebagai contoh, pada setiap acara walimah perkawinan, pemberi maw'izah hasanah (maksudnya nasihat perkawinan) hampir dapat dipastikan laki-laki sehingga isi khutbahnya selalu tertuju pada perempuan yang intinya istri harus taat pada suami. Akibatnya, dalam kebanyakan khutbah nikah, nyaris mempelai laki-laki tidak mendapatkan bekal atau arahan tentang bagaimana seharusnya menjadi suami yang baik dan ideal, sebagaimana diberikan kepada mempelai perempuan. Tentu saja hal itu merugikan laki-laki dan akibatnya, tidak banyak laki-laki mampu menjadi suami yang baik, apalagi ideal.

Kalangan perempuan NU mestinya berani tampil dan mengambil peran dalam upaya rekonstruksi fikih tersebut, sebab kitab fikih rupanya tidak selalu monopoli kaum laki-laki. Martin van Bruinessen (1995) menuturkan bahwa di antara kitab fikih yang banyak dibaca di Indonesia terdapat tulisan perempuan. Kitab dimaksud adalah kitab Perukunan Jamaluddin buah karya seorang perempuan bernama Fatimah, salah seorang cucu Syekh Arsyad al-Banjari, ulama terkenal asal Banjarmasin. Namun, masyarakat luas mengenal nama Jamaluddin, putra Syekh alBanjari sebagai penulisnya. Identitas pengarang yang sebenarnya sengaja disembunyikan sesuai dengan anggapan yang sudah mapan bahwa mengarang kitab merupakan pekerjaan laki-laki. Tidak mustahil kalau digali secara luas akan diketemukan kitab-kitab fikih lainnya hasil karya perempuan. Fakta tersebut sudah seharusnya menggugah kesadaran kritis perempuan NU untuk melakukan refleksi terus-menerus dalam rangka memajukan perempuan. 


\section{Kesimpulan}

Uraian tentang gerakan feminisme di Indonesia, khususnya di lingkungan Islam, dan lebih spesifik lagi di kalangan NU, menjelaskan kepada kita bahwa gerakan ini terus berkembang dan sangat dinamis, meskipun menghadapi sejumlah tantangan. Sejumlah isu yang selama ini diperjuangkan khususnya di bidang hukum, seperti persamaan hak untuk akses dan eksis di wilayah publik semakin terbuka dalam realitas kehidupan mereka.

Sejumlah persoalan lain masih menjadi agenda perjuangan feminis, di antaranya isu hak dan kesehatan reproduksi, isu trafficking (perdagangan) perempuan dan anak perempuan, isu buruh migran, perkawinan anak, poligami dan perkawinan kontrak. Selain itu, persoalan lain yang tidak kurang krusialnya adalah kekerasan terhadap perempuan dalam rumah tangga (domestic violence) dan isu gender mainstreaming dalam berbagai posisi strategis di lembaga-lembaga eksekutif, legislatif, dan yudikatif serta lembaga strategis lainnya. Namun demikian satu hal yang pasti bahwa gerakan feminisme di Indonesia sangat dipengaruhi dan juga mempengaruhi berbagai perubahan di bidang politik, sosial, hukum, dan ekonomi. Khusus bagi kalangan feminis di NU, tantangan untuk merekonstruksi fikih baru dan pemahaman keagamaan yang berperspektif perempuan masih menjadi agenda yang selalu menarik diperbincangkan.[a]

\section{DAFTAR PUSTAKA}

Abū Zayd, Nașr Ḥāmid, Mafhūm 'n-Naș: Dirāsāt fi 'Ulūm al-Qur'ān, Kairo: al-Hayyah al-Mișriyyah al-'Āmmah li 'l-Kitāb, 1993.

Bervson, Valerie, Feminist Political Theory an Introduction, London: Mac Millan, London, 1992.

al-Ghazālī, Abū Ḥāmid Muhammad, Al-Mustaşã min 'ilm al-Ușūl, Jedah: Sharikat alMadīnah al-Munawwarah li 'l-Tibā'ah, t.th.

Ibn 'Abd al-Salām, 'Izz al-Dīn, Qawāid al-Aḥkām fi Mașālị̣ al-Anām, t.t.p.: Dār al-Jīl, t.th.

Ibn Rushd, Fașl al-Maqāl fi Taqrīr mā bayna 'l-Sharīat wa '-Hikmah min 'l-Ittișāl aw Wujūh al-Nazar al-'Aqli wa Hudūd at-Ta wīl, Beirut: Dirāsah al-Wiḥdah al'Arabiyyah, 1999.

al-Jawziyyah, Ibn al-Qayyim, I'lām al-Muwaqqi'inn an Rabb al-'Alamīn, Juz III, Beirut: Dār al-jīl, t.th.

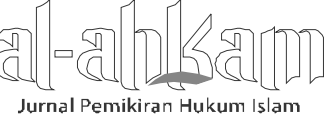

Volume 23, Nomor 1, April 2013 
Musdah Mulia

al-Juwaynī, Abū 'l-Ma'ālī, Al-Burhān fi Ușūl al-Fiqh, Beirut: Dār al-Kutb al-'Ilmiyyah, 1997.

Khallāf, 'Abdul Wahhāb, 'Ilm Ușul I-Fiqh, Cet. VII, Kairo: t.t.p., 1956.

PP Fatayat NU Sejarah Fatayat NU, , Jakarta, t.p, 2005.

al-Shātịī, Abū Ishāà, al-Muwāfaqāt fi Ușūl al-Sharīah, Kairo: Musțafā Aḥmad, t.th.

56 || Volume 23, Nomor 1, April 2013 